\title{
Pharmacology of fragrance: odors and GPCRs
}

\author{
Stuart Firestein \\ From 1st International Workshop on Odor Spaces \\ Hannover, Germany. 4-7 September 2013
}

Odor receptors are the largest family of GPCR's on the planet. The identification of this large family of genes by Buck and Axel in 1991 showed that they have much in common with the other 450 or so GPCRs found in the mammalian genome. From this one might imagine that they can be profitably studied by using techniques developed for standard GPCR pharmacology - ligand screening, structure activity relations, and a variety of modeling techniques. We have utilized synthetic chemistry to examine the structure-function activity of an odor receptor by utilizing a variety of synthetically designed ligands that demonstrate mechanisms for agonism, antagonism, partial agonism and reverse agonism. These analyses provide a theoretical picture of the requirements for a binding region within the receptor. The existence of a range of ligands - from antagonists to high affinity agonists for a given receptor must be taken into account when considering the type of upstream brain circuits that might be required to reduce the complex diversity of odor stimuli to the simpler categories of fragrance perception. In addition to these common principles of pharmacology that can be applied profitably to odor receptors we suggest that the techniques and strategies of medicinal chemistry, normally targeted to a single specific receptor (e.g., dopamine, epinephrine, serotonin) can be modified for use in a large and varied receptor population. The med chem concept of bioisosterism, for example, may help to better define our thinking about broad and narrow tuning in receptors when applied to large numbers of receptors.

Published: 16 April 2014

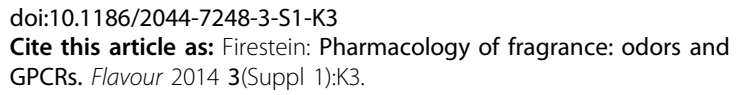

Department of Biological Sciences, Columbia University, New York, NY 10027, USA

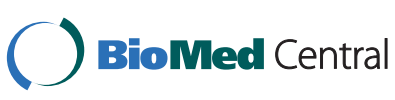

(c) 2014 Firestein; licensee BioMed Central Ltd. This is an Open Access article distributed under the terms of the Creative Commons Attribution License (http://creativecommons.org/licenses/by/2.0), which permits unrestricted use, distribution, and reproduction in any medium, provided the original work is properly cited. The Creative Commons Public Domain Dedication waiver (http:// creativecommons.org/publicdomain/zero/1.0/) applies to the data made available in this article, unless otherwise stated.

Submit your next manuscript to BioMed Central and take full advantage of:

- Convenient online submission

- Thorough peer review

- No space constraints or color figure charges

- Immediate publication on acceptance

- Inclusion in PubMed, CAS, Scopus and Google Scholar

- Research which is freely available for redistribution 